\title{
Genetic variability among isolates of Coconut lethal yellowing phytoplasmas determined by Heteroduplex Mobility Assay (HMA)
}

\author{
Vera Lucia A. Marinho*, Sandrine Fabre \& Michel Dollet \\ CIRAD, UPR29, Campus International de Baillarguet, 34398 Montpellier Cedex 5, France
}

Author for correspondence : Vera Lucia A. Marinho, e-mail: marinho.vera@gmail.com

\begin{abstract}
Heteroduplex mobility assay (HMA) was used to determine genomic diversity among African isolates of coconut lethal yellowing phytoplasmas causing Cape St. Paul wilt disease (CSPD, Ghana), lethal disease (LD, Tanzania), and lethal yellowing (LYM, Mozambique). They were also compared to the Caribbean phytoplasma associated with coconut lethal yellowing (LY). A DNA fragment of 1850 bp covering the 16S rRNA gene and 16/23S intergenic spacer region of each isolate was amplified with primers P1 and P7 and subsequently submitted to HMA analysis for sequence variation. A PCR product amplified from GH5D (CSPD isolate) as a reference was combined with each PCR product and electrophoresed on polyacrylamide gels. Three groups of phytoplasmas associated with various coconut lethal yellowing diseases were identified by HMA. The samples from Mozambique (LYM) and Ghana (CSPD) formed one group, which was different from the second group, LD from Tanzania. These two groups were different from the third group of Caribbean isolates. This grouping was consistent with the genetic diversity described in the coconut yellowing-associated phytoplasmas detected after cloning, sequencing, and phylogenetic analyses. The HMA technique described here has the potential to provide a simple and rapid means to identify and to establish the diversity of isolates within the coconut lethal yellowing disease group.
\end{abstract}

Keywords: Phytoplasmas, Coconut lethal disease, genomic diversity.

\section{RESUMO}

Variabilidade genética entre isolados do Coconut lethal yellowing phytoplasmas determinada pela mobilidade eletroforética dos ADNs heteroduplexes

A mobilidade eletroforética dos ADNs heteroduplexes foi usada para determinar a diversidade genômica entre isolados africanos dos fitoplasmas do amarelecimento letal dos coqueiros que causam as doenças denominadas, Cape St. Paul wilt disease (CSPD, Gana), lethal disease (LD, Tanzânia) e o lethal yellowing (LYM, Moçambique). Eles foram também comparados com o fitoplasma do Caribe que causa o Coconut lethal yellowing (LY). Fragmentos de ADN de 1850 pb, cobrindo a região do 16S rRNA e a região intergênica 16S-23S rRNA, de cada isolado, foram amplificados com os primers universais P1/P7 e submetidos a análise por HMA. Um produto de PCR amplificado a partir de ADN obtido do isolado GH5D, CSPD-Ghana, foi usado como referência e combinado com cada um dos produtos PCR dos outros isolados e submetidos à eletroforese em gel de poliacrilamida. Três grupos de fitoplasmas associados a várias doenças de amarelecimento letal de coqueiros foram identificados por HMA. As amostras de Moçambique (LYM) e Ghana (CSPD) formam um grupo que difere do segundo grupo, LD da Tanzânia. Esses dois grupos são diferentes do terceiro grupo formado pelos isolados do Caribe. Esses resultados foram consistentes com aqueles que demonstraram a diversidade genética para o complexo do LY através de clonagem, seqüenciamento e análises filogenéticas. A técnica de HMA demonstrou ser um método simples e rápido para identificar e estabelecer a diversidade de isolados dentro do grupo das doenças do amarelecimento letal dos coqueiros.

Palavras-chave: Fitoplasmas, amarelecimento letal do coqueiro, diversidade genômica.

Phytoplasmas are known to be the causal agents of lethal yellowing diseases (LYD) of coconut (Cocos nucifera), which are thought to have been endemic to the Caribbean since the end of the $19^{\text {th }}$ century and to West Africa since 1930. However, diagnosis of phytoplasma diseases by electron microscopy has only been possible since the 1970s. Polymerase chain reaction (PCR) diagnosis is now routinely

\footnotetext{
*Present Address: Embrapa Recursos Genéticos e Biotecnologia, Parque Estação Biológica, 70770-900, Brasília, DF, Brazil.
}

used for coconut lethal yellowing (LY) in the Caribbean. Two strategies allow the study of genetic variability in PCR products: restriction fragment length polymorphisms (RFLP) or sequencing, both of which require considerable time and expense. Heteroduplex mobility assay (HMA) is a fast and inexpensive method for determining relatedness between DNA sequences. It was developed by Delwart et al.. (1993) to evaluate viral heterogeneity and for genetic typing of human immunodeficiency virus (HIV).

Wang \& Griffith (1991) studied the effect of a single base deletion on the electrophoresis of heteroduplex DNA 
in cross-linked gels. The DNAs containing a single base deletion in one strand resulted in a bulge in the other strand and were electrophoretically retarded in comparison to DNAs with no bulges (Arens, 1999). Heteroduplexes are formed when two non-identical but closely related single-stranded DNA fragments anneal. Such molecules will have structural distortions at mismatched base pairs and at unpaired bases where an insertion or a deletion in the nucleotide sequence has occurred (Upchurch et al., 2000). Heteroduplexes migrate more slowly than a homoduplex in polyacrylamide gel electrophoresis. The extent of this retardation has been shown to be proportional to the degree of divergence between the two DNA sequences. The presence of an unpaired base is known to influence the mobility of a heteroduplex more than a mismatched nucleotide (Wang \& Griffith, 1991, Upchurch et al., 2000).

The HMA method has been used to characterize the variability of plant virus and phytoplasma diseases. HMA has been used for differentiation of phytoplasmas in the aster yellows group and clover proliferation group (Wang \& Hiruki, 2001), determination of genetic variability among isolates of Australian grapevine phytoplasmas (Constable and Symons, 2004), study of the genetic diversity of 62 phytoplasma isolates from North America, Europe and Asia (Wang \& Hiruki, 2005), and for phylogenetic relationships among flavescence dorée strains and related phytoplasmas belonging to the elm yellows group (Angelini et al., 2003). We used HMA to investigate the genetic variability of various isolates of African LYD phytoplasmas associated with Cape St. Paul wilt disease (CSPD, Ghana), lethal disease (LD, Tanzania), and lethal yellowing (LYM, Mozambique). They were also compared to the Caribbean phytoplasma associated with LY.

Thirty-six isolates from coconut trees infected with lethal yellowing diseases were used in this study: 15 from Ghana (GH1D - GH15D, Western Region), 14 from Tanzania (Tanz 1 -Tanz 14, Bagamoyo district, Pwani Region), three from Mozambique (LYM3, LYM12, LYM18, from Zambezia province), one from Mexico (Yucatan), one from Cuba (Cuba 166, Granma State), one from Honduras (Atlantic coast), and one from Jamaica. The DNA from an isolate of the clover phyllody phytoplasma (D62 Dijon, France) was used as the experimental control. Healthy coconut plants were also used as controls. Total DNA wasextracted from each sample using a DNeasy plant DNA extraction Kit (Qiagen) according to the manufacturer's instructions.

Phytoplasma infection was investigated by PCR employing phytoplasma "universal primers" P1 (Deng \& Hiruki, 1991) and P7 (Smart et al., 1996), designed to amplify the large DNA fragment comprising the entire 16S rRNA and 16/23S spacer region. The PCR reaction was performed in a final volume of $50 \mu \mathrm{L}$ reaction containing about $200 \mu \mathrm{M}$ mixed deoxynucleotide triphosphates (dNTPs), $100 \mathrm{ng}$ of each primer, 1.25 units of Taq DNA polymerase (Taq PCR Core Kit, Qiagen), 5X PCR buffer supplied with the enzyme, and $50 \mathrm{ng}$ of template DNA.
Using the universal primer set, PCR was carried out for 35 cycles under the following conditions: denaturation for 30 $\mathrm{s}\left(1 \mathrm{~min} 30 \mathrm{~s}\right.$ for first cycle) at $94^{\circ} \mathrm{C}$, annealing for $50 \mathrm{~s}$ at $56^{\circ} \mathrm{C}$, and extension for $1 \mathrm{~min} 30 \mathrm{~s}$ at $72^{\circ} \mathrm{C}$. Reactions were terminated after the 35 cycles with a 10 min extension step at $72^{\circ} \mathrm{C}$ and cooled to $4^{\circ} \mathrm{C}$. After amplification, $8 \mu \mathrm{L}$ from each sample was subjected to electrophoresis in $1 \%$ agarose gel using $1 \mathrm{X}$ TBE (0.089 M Tris, $0.089 \mathrm{M}$ borate, 2mM EDTA) running buffer and visualized by UV light after staining with ethidium bromide.

HMA analysis was adapted from previously described methods for the study of genetic variability between virus isolates (Delwart \& Gordon, 1997; Ellis \& Zambon, 2001, Berry \& Rey, 2001) and phytoplasmas (Constable \& Symons, 2004; Wang \& Hiruki, 2005).

The 16/23S spacer region and 16S rDNA gene amplified by PCR from different LYD phytoplasmas were analyzed by HMA. A $5 \mu \mathrm{l}$ aliquot of the PCR product amplified from GH5D (from Ghana) as a reference was combined with $5 \mu 1$ of each PCR product amplified from the thirty-six isolates from coconut trees infected with the respective phytoplasmas. For each combination, $2 \mu 1$ of annealing buffer (100 mM Tris- $\mathrm{HCl}$ at $\mathrm{pH} 8.0,20 \mathrm{mM}$ EDTA, and $1 \mathrm{M} \mathrm{NaCl}$ ) was added. One drop of mineral oil was overlaid on the reaction mixture. Samples were then denatured at $98^{\circ} \mathrm{C}$ for $4 \mathrm{~min}$, rapidly cooled to $4^{\circ} \mathrm{C}$, and then placed on ice for $20 \mathrm{~min}$. Samples were electrophoresed on $5 \%$ non-denaturing polyacrylamide gels (acrylamide:bis 29:1) in $1 \mathrm{X}$ TBE buffer at $230 \mathrm{~V}$ for $4 \mathrm{~h}$ at room temperature. The migration of heteroduplexes was also verified on $2 \%$ agarose gel in 1XTBE. DNA bands were stained in ethidium bromide and visualized under a UV transilluminator.

When the primers $\mathrm{P} 1 / \mathrm{P} 7$ were used, DNA fragments of approximately $1.8 \mathrm{~kb}$, the expected size, were obtained from all DNA samples from diseased plants, but not from healthy coconuts (data not shown). The PCR product obtained with the isolate GH 5 D (LYD from Ghana: Cape St. Paul wilt disease - CSPW) was used as a reference and combined with those amplified from each of the other phytoplasma samples. The DNA heteroduplexes were formed by pairwise combination of PCR-amplified fragment from GH5D and each of the other LY phytoplasmas. PCR products contain many heteroduplexes which are not resolved in agarose gel but may be resolved and appear as distinct bands in polyacrylamide gels.

When the heterologous DNA fragments were analysed by HMA in polyacrylamide gel, some bands migrated more slowly and were considered heteroduplexes between divergent DNA molecules during the process of denaturing and reannealing. These heteroduplexes were not observed when the reference PCR products were reannealed in homologous combinations (homoduplexes). A single band of $\sim 1800 \mathrm{bp}$, corresponding to the homoduplex, was observed when the PCR products of GH5D were combined with products from other CSPW isolates from Ghana or isolates of LYM (Mozambique) were tested. Heteroduplexes 
were formed between GH5D and LD-Tanzania (East Africa) isolates, LY-Cuba, LY-Mexico, LY-Jamaica (Caribbean region) and Clover phyllody phytoplasma from France (D62-Dijon).

A number of distinct homoduplex and heteroduplex patterns were observed (Figure 1). The isolates from Ghana and Mozambique (lanes 1-5) produced no heteroduplex, signifying that they are very closely related. The isolates from Tanzania (lanes 6-7) produced heteroduplexes with different mobilities, showing different profile from Ghana isolate, suggesting that these isolates are different. The Caribbean isolates (lanes: 8-Mexico, 9-Cuba, 10-Jamaica) produced heteroduplexes that differed in size from those formed between the Ghana and Tanzania isolates, showing different profile, suggesting that these isolates were different from Africa isolates. The clover phyllody phytoplasma (lane 11) differed substantially when paired with the PCR product of the Ghana isolate.

Post-amplification methods for rapidly analyzing variation in PCR amplicons include restriction fragment length polymorphism (RFLP) analysis and HMAs. RFLP assays of 16 rDNA PCR products have been described for the classification, identification and differentiation of phytoplasmas (Lee et al., 1993, Tymon et al., 1997; Mpunami et al., 1999; Harrison et al., 2002). A limitation of the method is that the presence of a mutation cannot be detected unless that mutation happens to fall within the recognition sequence of the restriction enzyme being used for digestion of the PCR products (Arens, 1999). Ultimately, HMA could be used for initial screening among a large number of isolates and rapid identification of virus, phytoplasmas and other organisms.

In this work, we used a combined PCR-HMA method to study genetic variability among isolates of coconut lethal yellowing diseases. Three groups of phytoplasmas associated with various LYD were identified. The samples from Mozambique (LYM) and Ghana (CSPW) formed one group, which was surprisingly different from the second group, LD from Tanzania, a country adjacent to Mozambique. These two groups were different from the third group of Caribbean isolates. This result confirmed, in one experiment, the genetic diversity described in the coconut yellowing-associated phytoplasmas detected after cloning, sequencing, and phylogenetic analyses (Tymon et al., 1998). The difference between the Tanzania and Mozambique isolates is worth further investigation.

In conclusion, the results show that combined $16 \mathrm{~S}$ rRNAgene PCR-HMA is a powerful tool for the identification and genetic characterization of coconut lethal yellowing phytoplasmas, and the test takes only 24 to $36 \mathrm{~h}$ to perform. The technique could also be applied to the other genes of coconut lethal yellowing phytoplasmas. This approach could be further developed to facilitate phylogenetic study and diagnosis of many other phytoplasmas and development of a comprehensive PCR-based classification system.

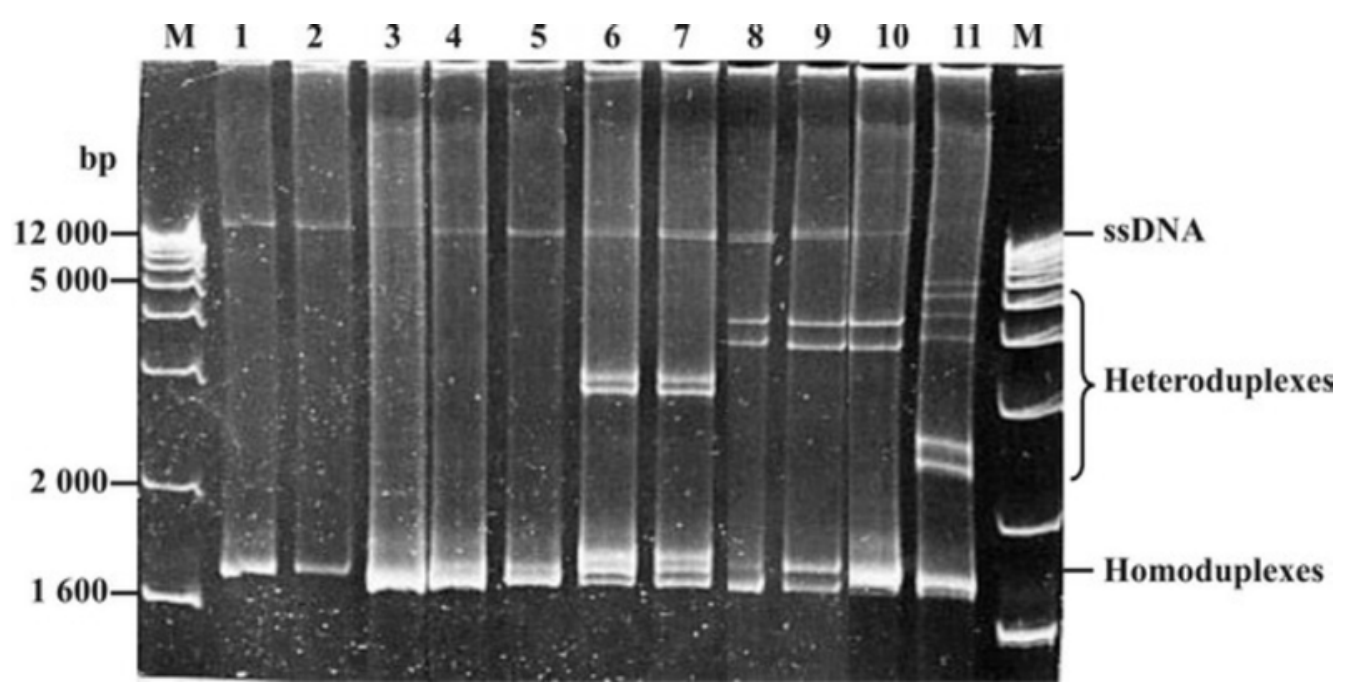

FIG. 1 - Heteroduplex mobility assay analysis of polymerase chain reaction-amplified 16S/23S spacer region from various phytoplasmas associated with coconut lethal yellowing. Heteroduplexes and homoduplexes were separated by electrophoresis in a 5\% polyacrylamide gel, stained in ethidium bromide, and visualized under a UV transilluminator. Cape St. Paul wilt disease -CSPD, Ghana (GH5D) was used as a reference. M. 1kb+ DNA Ladder; 1. GH5D/GH5D; 2. GH1D/GH5D; 3. GH6D/ GH5D (1-3 CSPD-Ghana); 4. LYM 12/ GH5D; 5. LYM 18/ GH5D (4-5 lethal yellowing - LYM, Mozambique); 6. LD 4/ GH5D, 7.LD11/ GH5D (6-7 lethal disease LD-Tanzania); 8. LY Mexico/ GH5D; 9. LY Cuba / GH5D; 10 Jamaica/ GH5D and 11. D62/ GH5D (Clover phyllody, Dijon 62) 


\section{ACKNOWLEDGMENTS}

We thank E. Boudon Padieu for Clover phyllody phytoplasma DNA, J. Mugini and A. Kullaya for LY-Tanzania DNA, W. Myrie for LY-Jamaica DNA, R. Llauger for LYCuba DNA; Carlos Oropeza for DNA from Mexico, and Maria-Mercedes de Roca for DNA from Honduras. We thank Serafina Mangana of Sanidad Vegetal from Mozambique (MD) and our colleagues from OPRI-CIRAD laboratory in Takoradi (Ghana) for helping us in sample collection. The first author also thanks EMBRAPA (Brazilian Enterprise for Agricultural Research), which provided financial support for her post-doctoral fellowship.

\section{REFERENCES}

Angelini E, Negrisolo E, Clair D, Borgo M, Boudon-Padieu E (2003) Phylogenetic relationships among Flavescence dorée strains and related phytoplasmas determined by heteroduplex mobility assay and sequence of ribosomal and nonribosomal DNA. Plant Pathology 52:663-672.

Arens M (1999) Methods for subtyping and molecular comparison of human viral genomes. Clinical Microbiology Reviews 12:612626.

Berry S, Rey MEC (2001) Differentiation of cassava-infecting begomoviruses using heteroduplex mobility assay. Journal of Virological Methods 92:151-163.

Constable FE, Symons RH (2004) Genetic variability amongst isolates of Australian grapevine phytoplasmas. Australasian Plant Pathology 33:115-119.

Delwart EL, Gordon CJ (1997) Tracking changes in HIV-1 envelope quasispecies using DNA heteroduplex analysis. Methods 12:348-354.

Delwart EL, Shpaer EG, Mccutchan FE, Louwagie J, Grez M, Rübsamen-Waigmann H. \& Mullins J I (1993) Genetic relationships determined by a DNA heteroduplex mobility assay: analysis of HIV-1 env genes. Science 262:1257-1261.

Deng S, Hiruki C (1991) Amplification of 16S rRNA genes from culturable and nonculturable Mollicutes. Journal of Microbiological Methods 14: 53-61.
Ellis JS, Zambon MC (2001) Combined PCR-heteroduplex mobility assay for detection and differentiation of influenza A viruses from different animal species. Journal of Clinical Microbiology 39:40974102.

Harrison NA, Myrie W, Jones P, Carpio ML, Castillo M, Doyle MM, Oropeza C (2002) 16S rRNA interoperon sequences heterogeneity distinguishes strain populations of palm letal yellowing phytoplasmas in the Caribbean region. Annals of Applied Biology 141:183-193.

Lee I.M, Hammond RW, Davis RE, Gundersen DE (1993) Universal amplification and analysis of pathogen 16S rDNA for classification and identification of mycoplasmlike organisms. Phytopathology 83:834-842.

Mpunami AA, Tymon A, Jones P, Dickinson MJ (1999) Genetic diversity in the coconut lethal yellowing disease phytoplasmas of East Africa. Plant Pathology 48:109-114.

Smart C, Schneider B, Blomquist CL, Guerra LJ, Harrison NA, Ahrens U, Lorenz KH, Seemüller E, Kirkpatrick BC (1996) Phytoplasma-specific PCR primers based on sequences of the 16/23S rRNA spacer region. Applied and Environmental Microbiology 62:2988-2993.

Tymon AM, Jones P, Harrison NA (1997) Detection and differentiation of African coconut phytoplasmas: RFLP analysis of PCR-amplified 16 rDNA and DNA hybridisation. Annals of Applied Biology 131:91-102.

Tymon AM, Jones P, Harrison NA (1998) Phylogenetic relationships of coconut phytoplasmas and the development of specific oligonucleotide PCR primers. Annals of Applied Biology 132:437-452.

Upchurch DA, Shankarappa R, Mullins JI (2000) Position and degree of mismatches and the mobility of DNA heteroduplexes. Nucleic Acids Research 28, no. 12, E69-e69.

Wang K, Hiruki C (2001) Use of heteroduplex mobility assay for identification and differentiation of phytoplasmas in the aster yellows group and the clover proliferation group. Phytopathology 91:546-552.

Wang K, Hiruki C (2005) Distinctions between phytoplasmas at the subgroup level detected by heteroduplex mobility assay. Plant Pathology 54:625-633.

Wang YH, Griffith J (1991) Effects of bulge composition and flanking sequence on the kinking of DNA by bulged bases. Biochemistry 30:1358-1363.

Received 22 November 2007 - Accepted 12 November 2008 - TPP 7127 Associate Editor: F. Murilo Zerbini 